\title{
The human homologue of yeast CRM1 is in a dynamic subcomplex with CAN/Nup214 and a novel nuclear pore component Nup88
}

\author{
Maarten Fornerod ${ }^{1}$, Jan van Deursen ${ }^{1}$, \\ Sjozef van Baal' ${ }^{1}$, Albert Reynolds ${ }^{2}$, \\ Donna Davis ${ }^{3}$, K.Gopal Murti ${ }^{3}$, \\ Jack Fransen ${ }^{4}$ and Gerard Grosveld ${ }^{1,5}$
}

Departments of ${ }^{1}$ Genetics, ${ }^{2}$ Tumor Cell Biology and ${ }^{3}$ Virology and Molecular Biology, St Jude Children's Research Hospital, 332 N. Lauderdale, Memphis, TN 38105, USA and ${ }^{4}$ Department of Cell Biology and Histology, Faculty of Medical Sciences, Nijmegen, The Netherlands

${ }^{5}$ Corresponding author

The oncogenic nucleoporin CAN/Nup214 is essential in vertebrate cells. Its depletion results in defective nuclear protein import, inhibition of messenger RNA export and cell cycle arrest. We recently found that CAN associates with proteins of 88 and $112 \mathrm{kDa}$, which we have now cloned and characterized. The $88 \mathrm{kDa}$ protein is a novel nuclear pore complex (NPC) component, which we have named Nup88. Depletion of CAN from the NPC results in concomitant loss of Nup88, indicating that the localization of Nup88 to the NPC is dependent on CAN binding. The $112 \mathrm{kDa}$ protein is the human homologue of yeast CRM1, a protein known to be required for maintenance of correct chromosome structure. This human CRM1 (hCRM1) localized to the NPC as well as to the nucleoplasm. Nuclear overexpression of the FG-repeat region of CAN, containing its hCRM1-interaction domain, resulted in depletion of hCRM1 from the NPC. In $C A N-/-$ mouse embryos lacking CAN, hCRM1 remained in the nuclear envelope, suggesting that this protein can also bind to other repeat-containing nucleoporins. Lastly, hCRM1 shares a domain of significant homology with importin- $\beta$, a cytoplasmic transport factor that interacts with nucleoporin repeat regions. We propose that hCRM1 is a soluble nuclear transport factor that interacts with the NPC.

Keywords: CAN/Nup214/CSE1/importin- $\beta /$ nuclear pore complex/nucleocytoplasmic transport

\section{Introduction}

The nuclear pore complex (NPC) is a $~ 125$ MDa complex embedded in the nuclear envelope (NE) that mediates bidirectional nucleocytoplasmic traffic in eukaryotic cells (recently reviewed by Panté and Aebi, 1994, 1996; Simos and Hurt, 1995; Görlich and Mattaj, 1996).

Although more than 30 NPC components have been isolated in both yeast and vertebrates, the interactions between the NPC and trafficking macromolecules are only recently beginning to be understood. The import of nuclear localization signal (NLS)-carrying proteins into the nucleus is mediated by a heterodimeric receptor complex. The smaller subunit of this complex, named importin- $\alpha$, NR- $\alpha$ or karyopherin- $\alpha$, binds directly to the NLS (Adam and Gerace, 1991; Adam and Adam, 1994; Görlich et al., 1994). The larger subunit, named p97, importin- $\beta$, NR- $\beta$ or karyopherin- $\beta$, is thought to mediate docking to the NPC. Importin- $\beta$ binds to several repeatcontaining nucleoporins in vitro, and certain nucleoporin repeats may act as the docking sites for the NLS import complex (Chi et al., 1995; Görlich et al., 1995b; Moroianu et al., 1995; Radu et al., 1995b). After docking, the import complex translocates though the central pore of the NPC, and the import substrate is released into the nucleoplasm in an energy-dependent manner, requiring the Ras-like GTPase Ran/TC4 (Melchior et al., 1993; Moore and Blobel, 1993; for a recent review, see Schlenstedt, 1996). Export of proteins and ribonucleoproteins (RNPs) from the nucleus is also an active process that uses some of the same factors involved in protein import, notably Ran/ TC4 (Schlenstedt et al., 1995) and importin- $\alpha$ (Görlich et al., 1996).

Within the NPC, several proteins interact in a genetic or physical manner. Co-purification studies in yeast showed that the nucleoporin Nsp1 forms one complex with the nucleoporins Nup49, Nup57 and Nic96 (Grandi et al., 1993), and forms a separate complex with Nup82 (Grandi et al., 1995). Other yeast proteins that physically interact include Srp1, Nup1 and Nup2 (Belanger et al., 1994). Interestingly, Srp1 is the yeast homologue of importin- $\alpha$. Recently, a yeast complex has been identified that includes nucleoporins Nup84, Nup120, Nup85 and also Sec13, which is involved in the transport of proteins from the endoplasmic reticulum to the Golgi apparatus (Siniossoglou et al., 1996). In higher eukaryotes, two protein subcomplexes have been identified, one containing nucleoporin p62, complexed with proteins of 58, 54 and $45 \mathrm{kDa}$ (Panté et al., 1994; Guan et al., 1995), and the second containing p250, associated with a protein of $75 \mathrm{kDa}$ (Panté et al., 1994). p62 is the metazoan homologue of yeast Nsp1, and p250 is probably identical to CAN/ Nup214.

The CAN protein was originally identified through its involvement in two types of acute myeloid or undifferentiated leukemia (von Lindern et al., 1992a,b). We have recently developed an in vivo approach to study the consequences of CAN depletion in knock-out mouse embryos. Using this approach, we found that the absence of CAN leads to simultaneous defects in nucleocytoplasmic transport and in cell cycle progression (van Deursen et al., 1996). Previously, we identified a new CAN-containing complex that included proteins of 88 and $112 \mathrm{kDa}$ (Fornerod et al., 1996). The central region of CAN associates with the $88 \mathrm{kDa}$ protein, most likely through coiled-coil interactions, whereas the $112 \mathrm{kDa}$ protein interacts with part of CAN's nucleoporin-specific 

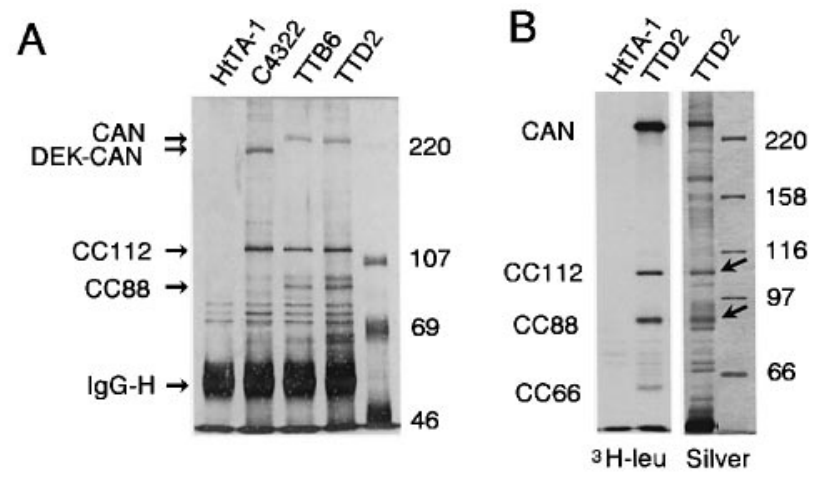

Fig. 1. Immunopurification of CAN-associating proteins. (A) Proteins immunoprecipitated with monoclonal antibody 12CA5 from cell lines expressing an HA1-tagged version of CAN (TTB6 and TTD2), DEK-CAN (C4322), and the parental cell line (HtTA-1), separated electrophoretically on $6 \%$ polyacrylamide gels and visualized with silver staining. The positions of CAN and DEK-CAN, as well as those of the coprecipitating proteins $\mathrm{CC} 112$ and $\mathrm{CC} 88$, are indicated by arrows. A molecular weight standard is indicated on the right. IgG-H, immunoglobulin heavy chain. (B) An aliquot $(0.1 \%)$ of the large-scale immunopurification of $\mathrm{CAN}$-associating proteins from the TTD2 cell line, run on a $6 \%$ polyacrylamide gel and silver stained. Arrows indicate the 112 and $88 \mathrm{kDa}$ copurifying proteins, and molecular weight markers are shown in an adjacent lane (right panel). As a reference, HA1-CAN was coprecipitated from $\left[{ }^{3} \mathrm{H}\right]$ leucinelabeled TTD2 cells (left panel). The position of CAN and coprecipitating proteins CC112, CC88 and CC66 are indicated on the left.

repeat region. Identification of these proteins by molecular cloning could improve our understanding of the function of CAN in the NPC. In addition, CC112 might be important in the leukemic process associated with DEK-CAN and SET-CAN, because it interacts with these leukemiaspecific fusion proteins (Fornerod et al., 1996).

Here, we report the cloning and characterization of these 88 and $112 \mathrm{kDa}$ proteins. The $88 \mathrm{kDa}$ protein is a new nuclear pore component that we name Nup88. The $112 \mathrm{kDa}$ protein is the human homologue of yeast CRM1 and is located at the NPC and nucleus. We provide evidence that the human CRM1 protein binds multiple NPC components and moves between the nuclear pore and the nucleoplasm. We also identify a group of proteins that includes hCRM1, yeast CRM1 and importin- $\beta$, which may constitute a novel family of NPC-interacting transport factors.

\section{Results}

\section{Purification of CAN coprecipitating proteins}

We showed recently that two proteins specifically coimmunoprecipitate with CAN, one of $88 \mathrm{kDa}$ (CC88) and one of $112 \mathrm{kDa}$ (CC112) (Fornerod et al., 1996). To coprecipitate sufficient quantities of the 112 and $88 \mathrm{kDa}$ proteins for micro-amino acid sequence analysis, we created stable cell lines that express an HA1-tagged CAN protein. To avoid toxic effects of high CAN expression (Fornerod et al., 1995), we made use of the Tet-VP16 system (Gossen and Bujard, 1992) to repress HA1CAN during the transient phases of transfection. Two independent, stably transfected cell clones, TTB6 and TTD2, were analyzed for proteins that coprecipitate with CAN. As shown in Figure 1A, both cell lines coprecipitated the expected 88 and $112 \mathrm{kDa}$ proteins. In much the same way we generated C4322, expressing HA1-tagged DEKCAN (Fornerod et al., 1995). Only the $112 \mathrm{kDa}$ protein coprecipitated from this cell line. To visualize the coprecipitating proteins on a silver-stained gel (Figure 1A) we needed at least $10^{7}$ cells per immunoprecipitation.

For micro-amino acid sequence analysis, we scaled up the immunoprecipitation $\sim 1000$-fold, using cell line TTD2 (see Materials and methods). Proteins from the preparation were separated by SDS-PAGE (Figure 1B), and the 88 and $112 \mathrm{kDa}$ protein bands were excised from the gel. Quantities of a coprecipitating protein of $66 \mathrm{kDa}$ (CC66; Fornerod et al., 1996) were insufficient for further analysis. Gel slices containing 82 and 48 pmol of CC 88 and CC112 respectively were digested with trypsin in situ, and tryptic peptides were eluted, purified by preparative HPLC and then sequenced from the $\mathrm{N}$-termini. Two sequences of 16 amino acids were obtained from CC88, and CC112 yielded one sequence of seven amino acids (Table I). None of these sequences showed significant homology to known proteins; however, the two peptides derived from CC88 matched an uncharacterized human cDNA in the dBEST database (IMAGE clone 179414, Genebank Accession number H50498). Similarly, the peptide derived from CC112 matched a cDNA in the TIGR database (Clone HTTEU26, Human Genome Science, Rockville, MD). Interestingly, the amino acid sequence of the putative reading frame of this cDNA clone showed significant homology to a yeast protein of $115 \mathrm{kDa}$, named CRM1. To determine whether these cDNAs were indeed derived from mRNAs encoding CC88 and CC112, full-length cDNA sequences were obtained from a human placenta cDNA library using clones 179414 and HTTEU26 as probes.

\section{Sequence analysis of hCRM1 and Nup88}

The complete cDNA putatively encoding CC112 had an open reading frame of 1071 amino acids and encoded a protein with a predicted molecular mass of $123 \mathrm{kDa}$ (Figure 2A). This open reading frame showed high homology to Saccharomyces cerevisiae CRM1 (47\% identity, $67 \%$ similarity) and to the Schizosaccharomyces pombe homologue CRM1+ (52\% identity, 69\% similarity). We therefore named this protein hCRM1 (human CRM1). Further database searches revealed that the N-terminus of hCRM1 shared significant homology to the N-terminus of importin- $\beta$ (Figure $2 B$ ). Importin- $\beta$ is part of the nuclear protein import receptor and can bind CAN in vitro (Radu et al., 1995a). In addition we found that a group of largely uncharacterized yeast and vertebrate proteins of similar size (110-120 kDa) shared this homology domain, that we propose to name the CRIME domain (CRm1, IMportin $\beta$, Etcetera). The sequence divergence within the group was calculated according to Sneath and Sokal (1973) (Figure 2C).

The complete cDNA thought to encode CC88 had an open reading frame of 741 amino acids and a predicted molecular mass of $85 \mathrm{kDa}$ (Figure 3A). Because an unrelated protein named Nup85 already exists, we have named this protein Nup88. Database searches revealed no significant homology of Nup88 to known proteins. However, the C-terminal sequences of Nup88 are predicted to form a coiled-coil (Lupas et al., 1991; Figure 3B), an interaction domain often found in NPC proteins. 
Table I. Amino acid sequences of tryptic peptides derived from Nup88 and hCRM1 ${ }^{\mathrm{a}}$

\begin{tabular}{lll}
\hline Protein & Peptide/cDNA & Amino acid sequence \\
\hline Nup88 & CC88 peptide 50 & -GPSGGGEEPAL(S)QYQ(R) \\
& cDNA IMAGE 179414 & RGPSGGGEPAL S QYQ R \\
& CC88 peptide 63rep20 & -XQSPTEAEKPA(S)(S)(S/G)L(P/G)(K) \\
cDNA IMAGE 179414 & KNQSPTEAEKPA S S S L S S \\
hCRM1 & CC112 peptide 63rep20 & -LISGWVS(R) \\
& cDNA TIGR HTTEU26 & KLISGWVS R \\
\hline
\end{tabular}

${ }^{a}$ Compared with virtual translations of expressed sequence tags found in computer databases. Trypsin hydrolyses peptide bonds at the C-terminal side of lysine $(\mathrm{K})$ or arginine $(\mathrm{R})$.

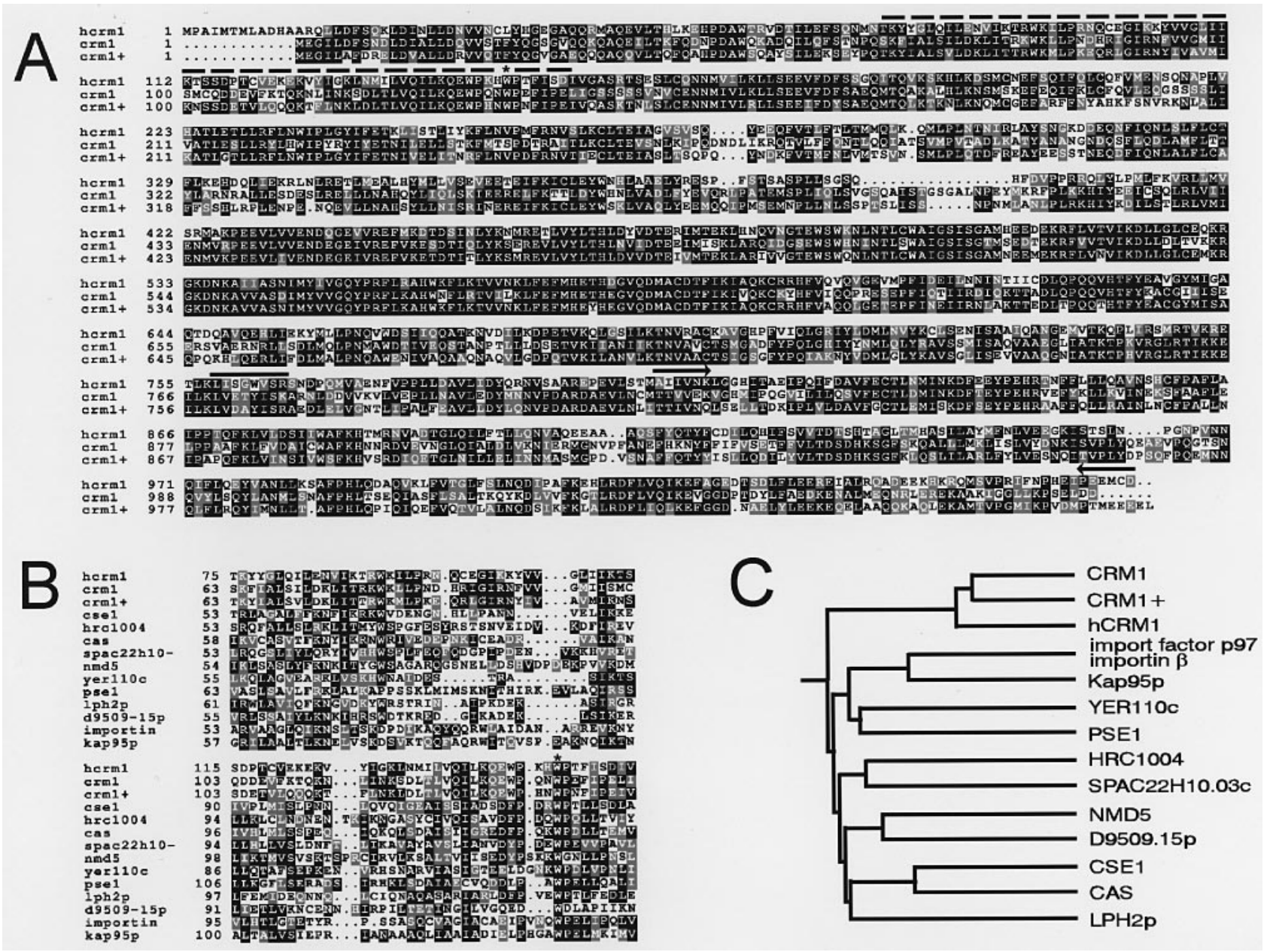

Fig. 2. Amino acid sequence of hCRM1. (A) Comparison between hCRM1, S.cerevisiae CRM1 (Adachi and Yanagida, 1989; Toda et al., 1992), and S.pombe CRM1 + (Toda et al., 1992). Identical and similar amino acids are boxed in black and gray respectively. The broken lines above the sequence denote the N-terminal homology domain and an asterisk indicates the conserved tryptophan. A bar indicates the position of peptide 63rep20. The amino acid sequences between the arrows were used to raise antibodies against the protein. (B) Comparison between hCRM1 amino acids 75-154 and similar N-terminal regions of S.cerevisiae CRM1, CSE1 (Xiao et al., 1993), Hrc1004 (Accession number S53939), Spac22H10.03c (Z69730), Nmd5 (P46970), Yer110c (P40069), Pse1 (Chow et al., 1992), Lph2p (U43503), D9505.15p (U32274), Kap95p (Görlich et al., 1995a), S.pombe CRM1+ and human CAS (Brinkmann et al., 1995). The tryptophan that is conserved in all proteins is marked with an asterisk. Alignments were calculated using the program Clustal W with a gap penalty of 10 and a gap extension penalty of 0.05 . (C) Dendrogram representing the sequence relationships between CRIME domain proteins. Relationships were calculated using the UPGMA algorithm (Sneath and Sokal, 1973) and were based on complete amino acid sequences.

\section{Interaction of Nup88 and hCRM1 with CAN}

To further study the Nup88 and hCRM1 proteins, and to confirm their interaction with CAN, we produced rabbit polyclonal antisera against amino acids 509-741 of Nup88 and amino acids 805-1071 of hCRM1 (Figures 2 and 3). These regions excluded the peptide sequences used to identify the Nup 88 and hCRM1 cDNAs.
To confirm that isolated cDNA sequences indeed encoded the 88 and $112 \mathrm{kDa} C A N$-associating proteins, we tested whether affinity-purified $\alpha$-Nup8 8 and $\alpha$-hCRM1 antisera could detect these proteins in CAN immunoprecipitates. Using IP-Western blot analysis (Figure 4A), we found that the $112 \mathrm{kDa}$ protein that was immunopurified from TTD2 or C4322 cells was recognized by 
antibodies against bacterially produced hCRM1. Similarly, the $88 \mathrm{kDa}$ protein that was immunopurified from TTD2 cells reacted with antibodies against bacterially produced Nup88. The $\alpha$-Nup88 antibodies also recognized a less
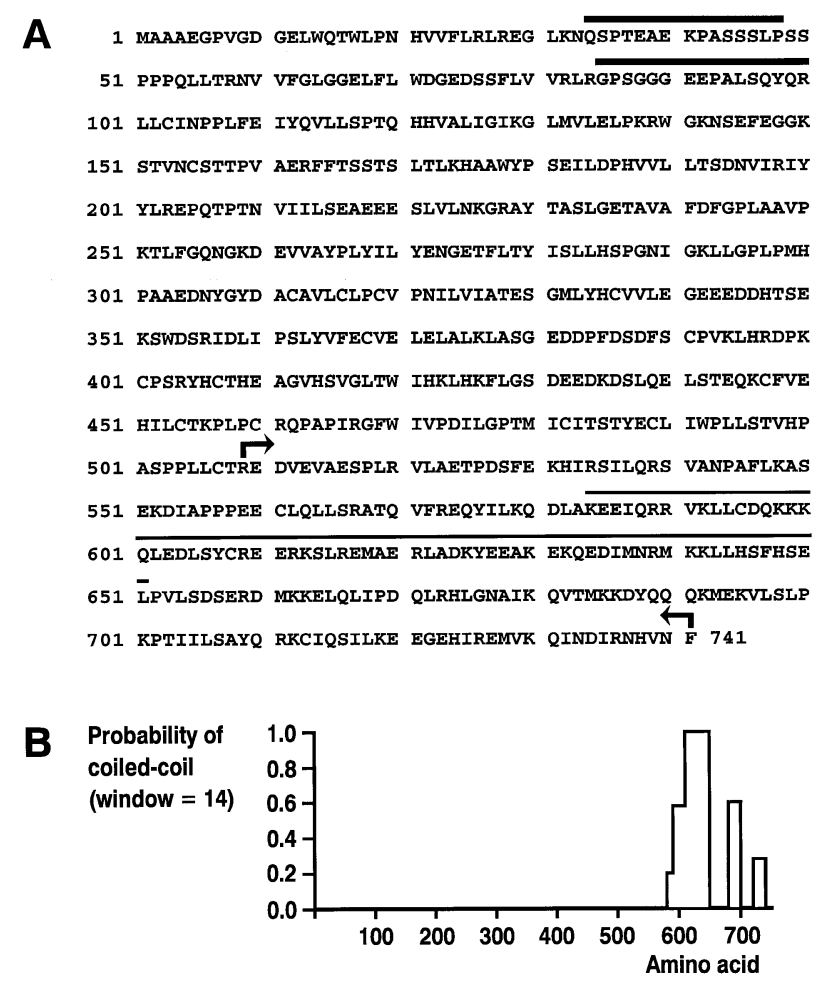

Fig. 3. Sequence characteristics of Nup88. (A) Predicted amino acid sequence of the Nup88 protein. Bars above the sequence indicate peptides 50 and 67rep23 respectively. Solid lines show predicted coiled-coil regions. The amino acid sequences between the arrows were used to raise antibodies to Nup88. (B) Prediction of coiled-coil regions within Nup88; the program PEPCOIL was used which identifies potential coiled-coil regions of protein sequences based on the algorithm of Lupas et al. (1991). abundant coprecipitating protein of $\sim 90 \mathrm{kDa}$. This protein possibly represents a post-translationally modified form of Nup88. These results provide evidence that the Nup88 and $h C R M 1$ genes encode CC88 and CC112, respectively.

We next assessed the cellular specificity of the affinitypurified $\alpha$-Nup88 and $\alpha$-hCRM1 antisera by using them to immunoprecipitate proteins from $\left[{ }^{3} \mathrm{H}\right]$ leucine-labeled HtTA-1 whole-cell extracts (Figure 4B). The antisera to hCRM1 and Nup88 specifically immunoprecipitated proteins of the correct sizes, relative to the proteins that coprecipitate with CAN. This indicates that the affinitypurified antisera to hCRM1 and Nup88 are monospecific and suitable reagents with which to further characterize the proteins.

When we tested whether the hCRM1- and Nup88specific antibodies would coprecipitate CAN, no precipitation was found. It is conceivable that these antibodies interfere with CAN association. For instance, in the case of Nup88, the serum may include antibodies against the predicted protein interaction domain (see Figure 3). Therefore, we linked the C-terminal 374 amino acids of Nup88, which contain this domain, to an HA1 tag and transiently expressed the product in HtTA-1 cells. Using monoclonal 12CA5 to the HA1 epitope, HA1-Nup88(368741) coprecipitated a protein of the size of hCRM1 (Figure 4B) that reacted with anti-hCRM1 antibodies in IPWestern analysis (not shown). Since hCRM1 does not directly coprecipitate with Nup88 (Fornerod et al., 1996), hCRM1 most likely is coprecipitated via CAN. Indeed, the immunoprecipitate also contained a protein of $\sim 220 \mathrm{kDa}$ (Figure 4B), the size of CAN. This result indicates that the C-terminal part of Nup88 contains the $\mathrm{CAN}$-interaction domain and confirms the existence of the CAN-hCRM1-Nup88 complex. Attempts to precipitate this complex using an N-terminally HA1-tagged hCRM1 were unsuccessful, which could be due to the aberrant subcellular localization of this protein, that appeared to be exclusively nuclear (data not shown).
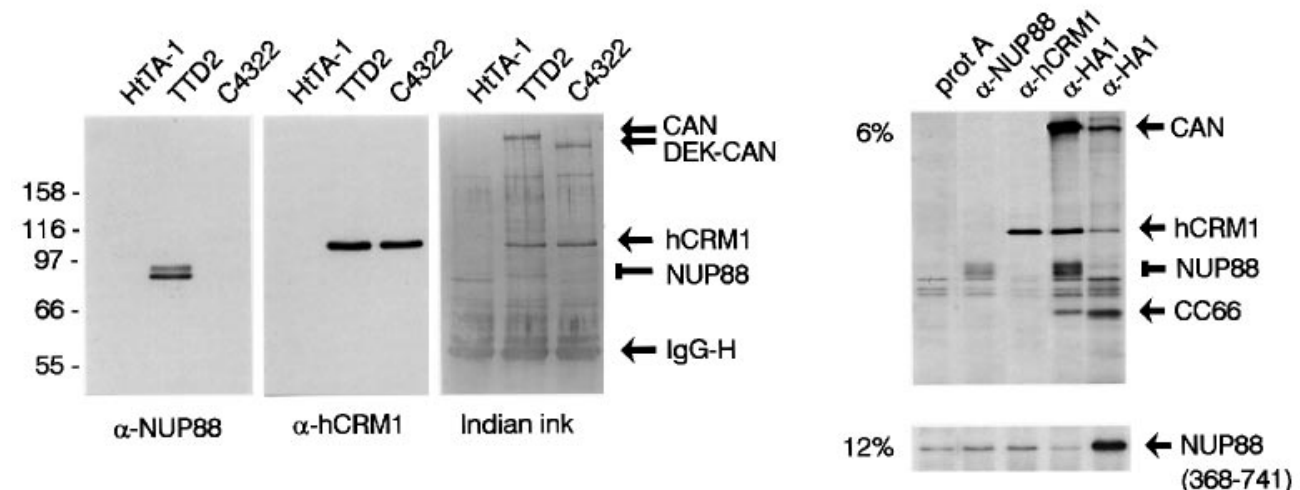

Fig. 4. Interaction of CAN, hCRM1 and Nup88. (A) Western blot analysis of proteins that coprecipitated with HA1-tagged CAN or DEK-CAN, using monoclonal 12CA5, from cell lines TTD2 and C4322, as indicated above the lanes. The parental cell line HtTA-1 served as a negative control. Blots were stained with india ink and incubated with antibodies to Nup88 or hCRM1, as indicated below the blots. Positions of CAN, DEK-CAN, hCRM1 and Nup88 are denoted on the right; IgG-H, immunoglobulin G heavy chain. Molecular weight standards are indicated on the left.

(B) Immunoprecipitation of proteins from $\left[{ }^{3} \mathrm{H}\right]$ leucine-labeled HtTA-1 cells with $\alpha$-Nup 88 or $\alpha$-hCRM1 antibodies, as indicated above the lanes. Protein A-Sepharose (prot A) served as a negative control. Anti-HA1 antibody $12 \mathrm{CA} 5$ was used to immunoprecipitate $\left[{ }^{3} \mathrm{H}\right]$ leucine-labeled proteins from HtTA-1 cells that transiently expressed HA1-CAN (second lane from right) or HA1-Nup88(368-741) (right lane). Positions of CAN, hCRM1, Nup88, CC66 and Nup88(368-741) are indicated on the right. The polyacrylamide gel percentages are indicated on the left. 

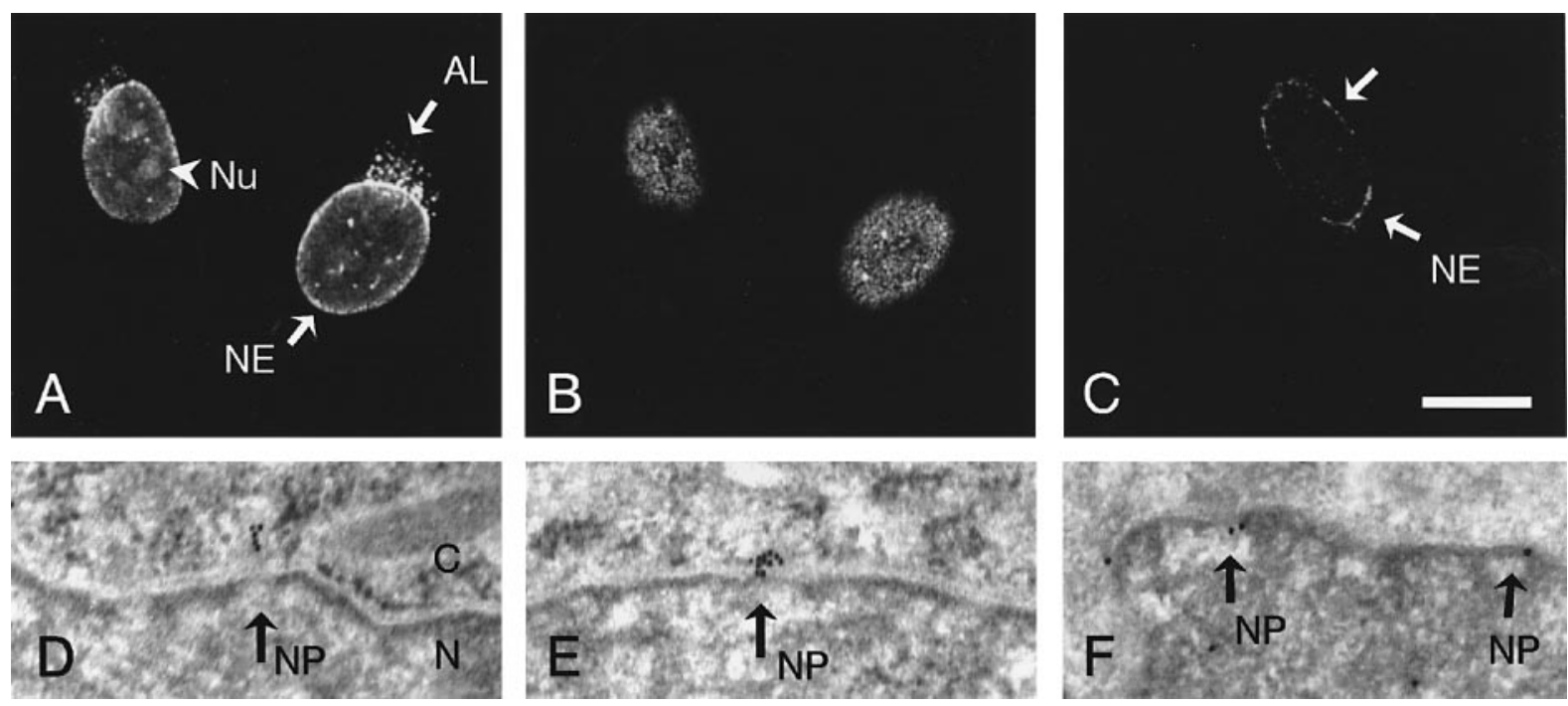

Fig. 5. Subcellular distribution of hCRM1 and Nup88 in HtTA-1 cells. (A-C) Indirect immunofluorescence with $\alpha$-hCRM1 (A and B) or $\alpha$-Nup88 (C) antibodies. (A) and (B) show the same cell, focused across (A) or on top of (B) the nucleus. Arrows indicate the nuclear envelope (NE) and structures resembling annulate lamellae (AL); an arrowhead marks a nucleolus (Nu) in (A). (D-F) Immunoelectron microscopic localization of hCRM1. Three cross-sections through the nuclear envelope are shown. The nuclear membrane is negatively stained. Gold particles decorate nuclear pores, indicated by arrows, at the cytoplasmic face (D and E) and at the nuclear face (E and F). NP, nuclear pore; C, cytoplasm; $\mathrm{N}$, nucleoplasm. The bar is $6 \mu \mathrm{m}$ in $\mathrm{A}-\mathrm{C}, 150 \mathrm{~nm}$ in D-F.

\section{Subcellular localization of hCRM1 and Nup88}

Because CAN localizes to the NPC, we anticipated that the proteins with which it interacts would also be present at that subcellular location. Moreover, the S.pombe and S.cerevisiae CRM1 proteins are known to localize to the nucleus and particularly the nuclear periphery (Adachi and Yanagida, 1989). We addressed the subcellular localization of the hCRM1 and Nup88 protein by indirect immunofluorescence. Our monospecific $\alpha$-hCRM1 antiserum showed a punctate rim staining around the nucleus (Figure 5A), which is a staining pattern characteristic for NPC proteins (Davis and Blobel, 1986). When focused on the nuclear surface, a dotted staining pattern was observed (Figure 5B), also characteristic for NPC proteins. Moreover, a specific signal was present in the nucleoplasm (Figure $5 \mathrm{~A}$ ), with the nucleoli often staining more strongly than the surrounding nucleoplasm. In the cytoplasm, the hCRM1specific signal was restricted to small dots. Since these dots also stain with monoclonal antibody 414, directed against a common nucleoporin epitope (Davis and Blobel, 1986), they most likely represent annulate lamellae (data not shown). Antibodies to Nup88 localized exclusively to the nuclear envelope (Figure 5C).

To obtain a more detailed understanding of the subcellular localization of hCRM1, we examined this protein by using immunoelectron microscopy on LRWhite-embedded ultrathin sections of HtTA-1 cells. Most of the CRM1-specific gold label appeared in the nucleus, and the gold density was highest at the nuclear envelope (data not shown). At the level of the nuclear pore, hCRM1 was present at both the cytoplasmic (Figure 5D and E) and nucleoplasmic face (Figure 5E and F) of the NPC. To confirm the localization at the level of the nuclear pore, we performed the same analysis on ultrathin cryosections of HtTA-1 cells. In such sections hCRM1-specific label was also found at both sides of the NPC, at approximately equal frequency (data not shown).

\section{hCRM1 and Nup88 in CAN-/- embryos}

Recently, we studied the phenotypic consequences of CAN depletion in early mouse embryos, homozygous for a knock-out mutation in the $C A N$ gene (van Deursen et al., 1996). Typically, depletion of CAN protein from maternal sources starts at around day 2.5 of gestation. By day 3.5, CAN is undetectable.

To investigate hCRM1 and Nup88 localization in CANdepleted embryos, we immunostained $C A N-/-$ and wildtype blastocysts that were cultured in vitro for $18 \mathrm{~h}$, with affinity-purified $\alpha$-hCRM1 and $\alpha$-Nup88 antibodies. Indirect immunofluorescence on wild-type embryos showed staining for hCRM1 within the nucleus and at the nuclear rim (Figure 6B, $n=6$ ), comparable with the staining pattern in human HtTA-1 cells. To confirm that the nuclear envelope was stained specifically, we performed a co-staining with monoclonal antibody 414 (Davis and Blobel, 1986), that recognizes a group of nucleoporins (Figure 6A and D). CAN-depleted embryos also showed a clear nuclear rim staining and a nuclear signal (Figure 6C, $n=5$ ). This result suggests that NPC association of hCRM1 is not dependent on CAN, and presumably can be mediated by other NPC components. Intriguingly, every cell of the mutant embryo showed prominent staining of the nucleolus, which was not observed in wild-type embryos.

Nup88 was detected at the nuclear envelope in the wildtype embryos (Figure 6E, $n=4$ ). This staining was absent or barely detectable in cells of $C A N-/-$ embryos (Figure $6 \mathrm{~F}, n=4)$, indicating that the interaction of Nup88 at the NPC is CAN dependent.

\section{hCRM1 displays dynamic behavior}

We have shown in HtTA-1 cells that hCRM1 appears in the nucleoplasm, the NPC, and in nucleoli. We then examined whether this localization represents a static 

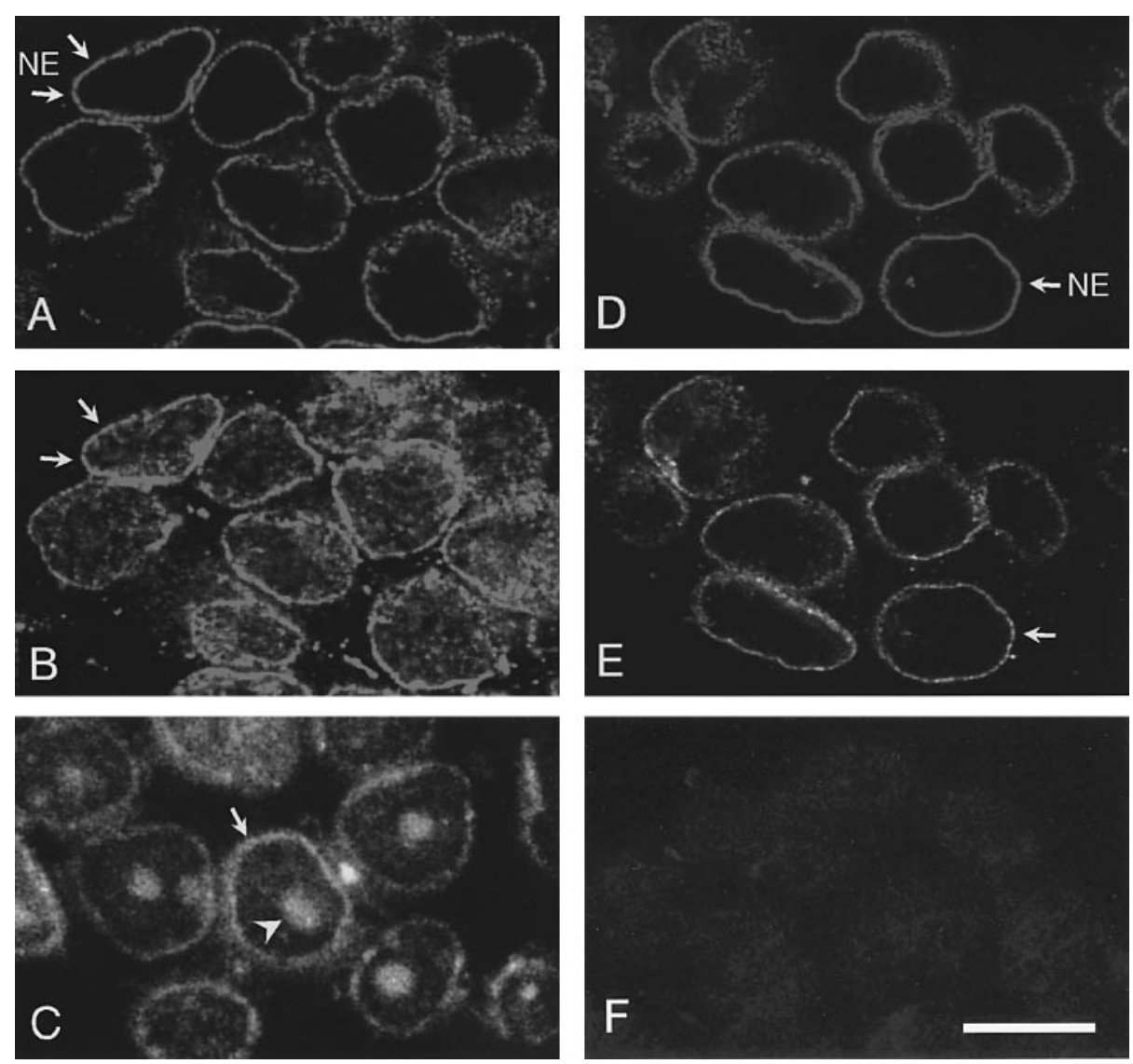

Fig. 6. Subcellular localization of hCRM1 (B and $\mathbf{C}$ ) and Nup88 (E and $\mathbf{F})$ in wild-type (B and E) or CAN-/- (C and F) blastocysts. The specificity of nuclear envelope staining is shown by co-localization of wild-type embryos with monoclonal 414 (A and D). Only part of the embryo is shown. Arrows point to the nuclear envelope; an arrowhead denotes a nucleolus in (C). NE, nuclear envelope. The bar represents $10 \mu \mathrm{m}$.

situation, or if there is trafficking of hCRM1 between these cellular compartments.

In previous studies, we found that the C-terminal part of CAN is located in the nucleus when expressed by itself (Fornerod et al., 1995). Moreover, this part of CAN includes the hCRM1-binding domain (Fornerod et al., 1996). If hCRM1 moves between the nuclear pore and the nucleoplasm, the presence in the nucleus of the CAN domain for hCRM1 binding might disturb hCRM1 intracellular routing. We therefore expressed the hCRM1binding domain of CAN (the C-terminal amino acids 1864-2090) transiently in HtTA-1 cells. By using indirect immunofluorescence, we could detect the transfected protein with monoclonal 12CA5 (Figure 7A), while, in the same cells, we could monitor endogenous hCRM1 localization by using $\alpha$-hCRM1 antibodies (Figure 7B). Expression of C-terminal CAN caused hCRM1 accumulation in the nucleus and its disappearance from the nuclear envelope, as we could verify by a double-labeling experiment with monoclonal 414, that specifically stains the nuclear envelope (data not shown). These results suggest that the hCRM1-binding domain of CAN is able to titrate hCRM1 from the NPC, and that the presence of hCRM1 at both the nuclear pore and in the nucleoplasm is a result of a dynamic exchange. However, if the turn-over time of hCRM1 is relatively short, nuclear hCRM1 accumulation could also be explained by newly synthesized hCRM1 becoming trapped in the nucleoplasm by C-terminal CAN.
We therefore determined the half-life of hCRM1 by pulsechase experiments, and found it to be $\sim 24 \mathrm{~h}$ (data not shown). This means that at least part of the hCRM1 protein that accumulates in the nucleus was originally located at the nuclear envelope.

As stated earlier, hCRM1 is present very prominently in the nucleoli of CAN-depleted embryos. Such accumulation could indicate that the phenotypic effects of CANdepletion include disruption of processes within the nucleolus. In an attempt to mimic such disturbances, we cultured HtTA-1 cells for $45 \mathrm{~min}$ in the presence of $0.04 \mu \mathrm{g} / \mathrm{ml}$ actinomycin $\mathrm{D}$, a compound which, at this concentration, specifically inhibits RNA polymerase Idependent transcription (Perry and Kelley, 1970). Cells cultured in the presence of actinomycin D distinctly accumulated hCRM1 in their nucleoli (Figure 7D). Higher concentrations of actinomycin D $(5 \mu \mathrm{g} / \mathrm{ml})$, which also affect RNA polymerase II-dependent transcription, had the same effect on hCRM1 localization (not shown). These results suggest that the nucleolus may be part of normal hCRM1 routing, and encourage the design of studies into the role of hCRM1 in nucleolar function and nucleolar/ NPC trafficking.

\section{Discussion}

The oncogenic nucleoporin CAN/Nup214 forms an NPC subcomplex with proteins of 88 and $112 \mathrm{kDa}$ (Fornerod 

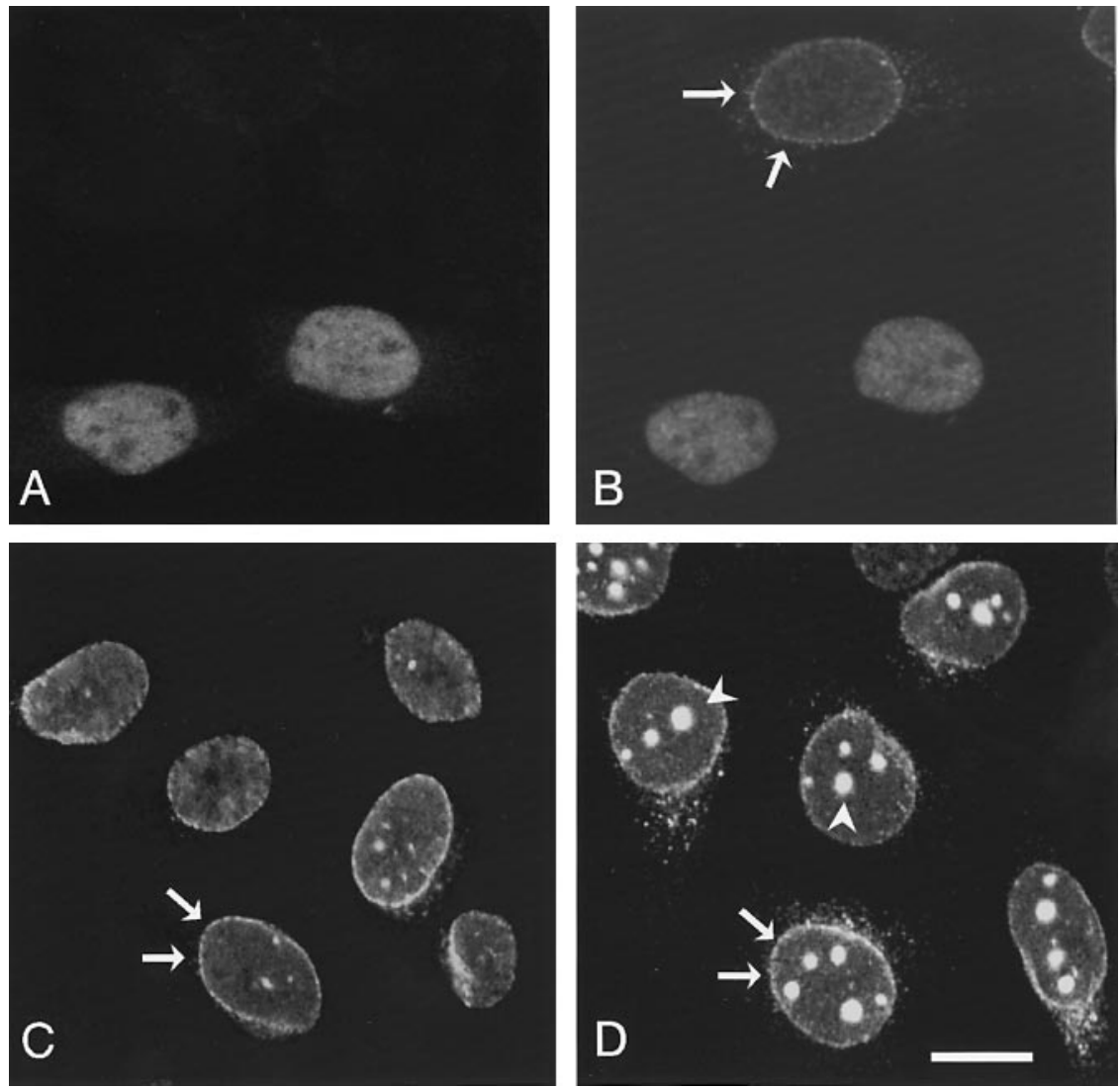

Fig. 7. hCRM1 displays dynamic behavior. (A and B) Double-stained HtTA-1 cells, transiently expressing the hCRM1 binding region of CAN, visualized with monoclonal 12CA5 (A). Endogenous hCRM1 is detected with $\alpha$-hCRM1 antibodies (B). Arrows indicate hCRM1 nuclear envelope staining in an untransfected cell. (C and D) hCRM1 protein localized by indirect immunofluorescence in normal HtTA-1 cells cultured for 45 min in the absence (C) or presence (D) of $0.04 \mu \mathrm{g} / \mathrm{ml}$ actinomycin D. Arrows indicate nuclear envelope staining, arrowheads point to nucleoli. The bar represents $8 \mu \mathrm{m}$.

et al., 1996). We immunopurified these two proteins and cloned their cDNAs via peptide sequencing.

The $88 \mathrm{kDa}$ protein is a novel nuclear pore component, which we have named Nup88. This protein may be identical to $\mathrm{p} 75$, a protein previously shown to copurify with CAN from rat liver extracts (Panté et al., 1994), although the difference in molecular weight seems to be considerable. Nup88 has no sequence homology to known proteins, but its $\mathrm{C}$-terminus contains sequences that are predicted to form a coiled-coil domain. Predicted coiledcoil regions have been found in several other nuclear pore proteins, including CAN (for a review, see Panté and Aebi, 1994), and are thought to mediate interactions within NPC subcomplexes. Previously, we showed that mutations in CAN's coiled-coiled regions inhibit CAN interaction with the $88 \mathrm{kDa}$ protein identified here as Nup88 (Fornerod et al., 1996). This result suggests that the Nup88-CAN interaction is coiled-coil-mediated. The position of the coiled-coil region of Nup88 is similar to that of S.cerevisiae Nup82p, a protein that, if mutated, causes mRNA export defects (Hurwitz and Blobel, 1995), as does mutation of CAN (van Deursen et al., 1996). However, the sequence homology between these proteins is marginal (data not shown), and it remains to be determined whether Nup88 could be the functional homologue of yeast Nup82p.

$C A N-/-$ mouse embryos that lack CAN have no detectable Nup88 at their nuclear envelopes. Therefore, the presence of Nup88 at the nuclear pore depends on its physical interaction with CAN. This implies that the phenotypic effects of CAN elimination, which include $\mathrm{G}_{2}$ arrest and changes in nucleocytoplasmic trafficking (van Deursen et al., 1996), may in part be caused by Nup88 depletion from the NPC.

Surprisingly, the $112 \mathrm{kDa}$ protein appeared to be the human homologue of S.cerevisiae and S.pombe CRM1, proteins not previously implicated in nucleocytoplasmic transport. The S.pombe crm1+ (chromosome region maintenance) gene was first identified as a mutated gene in certain cold-sensitive strains that display deformed chromosomes at the restrictive temperature (Adachi and Yanagida, 1989). Furthermore, mutations in the $\mathrm{crml}$ gene cause deregulation of the transcription factor papl (the budding yeast homologue of human AP1) (Toda et al., 1992), and can lead to multidrug resistance (Nishi et al. 1994; Turi et al., 1994). Mutations in yeast genes involved in nucleocytoplasmic trafficking can, apart from transport defects, lead to similar pleiotropic effects, as illustrated by the yeast homologue of the GTPase Ran/TC4, and its exchange factor RCC1 (Forrester et al., 1992; Kadowaki et al., 1993), and by Nup85p (Goldstein et al., 1996). It is therefore conceivable that a transport defect may be responsible for the $\mathrm{crml}$ phenotype. The yeast CRM1 proteins have been localized to the nucleus and are particularly prominent at the nuclear periphery (Adachi and Yanagida, 1989). This, together with the high homology between yeast and human CRM1, suggests that also 
in yeast, CRM1 may strongly associate with repeatcontaining nucleoporins.

The hCRM1 protein is identical to the $112 \mathrm{kDa}$ protein that interacts with DEK-CAN and SET-CAN, two nuclear fusion proteins associated with acute myeloid and undifferentiated leukemia, respectively (Fornerod et al., 1996). Because hCRM1 is not related to any proteins known to be involved in oncogenic transformation, its possible role in leukemogenesis remains to be determined. However, hCRM1 could be part of a novel pathway, via which nuclear pore components contribute to leukemogenesis.

\section{Is hCRM1 a novel transport factor?}

Several lines of evidence support the idea that hCRM1 could be a transport factor that interacts dynamically with the NPC.

First, the dual subcellular localization of hCRM1 to the nucleus and to the NPC suggests that this protein can travel between the two compartments. To test this, we overexpressed the hCRM1-binding domain of CAN, which is located in the nucleus and not at the NPC. If hCRM1 binds permanently to CAN, expression of its binding domain in the nucleus would have no effect. If, on the other hand, hCRM1 is released periodically from the NPC into the nucleus, the presence of an excess binding domain could sequester the hCRM1 in the nucleoplasm and lead to a gradual disappearance of hCRM1 from the nuclear envelope. We found that, under these conditions, hCRM1 was completely absent from the nuclear envelope and was only present in the nucleoplasm. Since we showed that the half-life of hCRM1 is long, this suggests that hCRM1 can move from the NPC to the nucleoplasm. In addition, we have shown that repression of RNA polymerase I-dependent transcription causes accumulation of hCRM1 in the nucleolus. Although we do not understand the mechanism causing this effect, it does suggest that hCRM1 routing involves the nucleolus.

Second, the nuclear envelopes of cells from CANdepleted mouse embryos contain hCRM1. This suggests that hCRM1 can bind to NPC components other than CAN. We previously demonstrated that hCRM1 interacts with the C-terminal half of CAN's nucleoporin repeat region (Fornerod et al., 1996). This repeat of CAN has significant homology to repeats of several other nucleoporins, including Nup98, Nup153 and p62. Thus, hCRM1 may interact with repeat regions of these, or other yet unknown, vertebrate nucleoporins. In agreement with this is our observation that hCRM1 is present at the nuclear as well as the cytoplasmic face of the NPC, while CAN is only present at the cytoplasmic side (Kraemer et al., 1994). Therefore, Nup98 and Nup153 are good candidates to mediate additional nuclear NPC association of hCRM1, as both reside at the nuclear face of the NPC (Sukegawa and Blobel, 1993; Radu et al., 1995b).

Third, hCRM1 shares a region of significant homology with importin- $\beta$. This factor interacts physically with nucleoporin-specific repeat regions (Moroianu et al., 1995; Radu et al., 1995b) and can bind CAN in ligand blot assays (Radu et al., 1995a). This suggests that hCRM1 and importin- $\beta$ may interact with the NPC by the same mechanism. Importin- $\beta$ forms part of a cytoplasmic transport complex that mediates protein import into the nucleus. Two molecular mechanisms have been proposed for the translocation of this protein-import complex through the NPC (Rexach and Blobel, 1995; Görlich and Mattaj, 1996; Nehrbass and Blobel, 1996). Both models propose a stepwise binding and release of the importin- $\beta$ component of the complex to and from nucleoporin repeats. Because the different nucleoporins localize to specific sites along the NPC, the transport direction of the complex is proposed to be established via an increased binding affinity of importin- $\beta$ for nucleoporin repeats towards the nucleus. Following these models, the more cytoplasmically located CAN would have a relatively weak affinity for importin- $\beta$, which is in agreement with its absence in our CAN co-immunoprecipitation experiments. In contrast, hCRM1 appears to have a high affinity for CAN. This suggests that if hCRM1 interacts with nucleoporin repeats in an importin- $\beta$-like fashion, it could move in the opposite direction, i.e. from the nucleus to the cytoplasmic face of the NPC.

In addition to importin- $\beta$ and its yeast homologue Kap95p, we found nine other proteins that share the $\mathrm{N}$ terminal CRIME domain. The majority of these proteins came from hypothetical open reading frames identified as part of the S.cerevisiae genome sequencing project. However, CSE1 has been identified as an essential yeast protein, and its mutation results in a chromosome segregation defect (Xiao et al., 1993). Moreover, it was reported that the csel phenotype can be suppressed by high expression of Srp1 (Belanger et al., 1994), the yeast importin- $\alpha$ homologue that interacts with the nucleoporins Nup1 and Nup2. Thus, CSE1 is the third otherwise unrelated protein that shares the $\mathrm{N}$-terminal domain and is implicated in NPC interaction. Therefore, this Nterminal homology domain may define a new group of NPC-interacting transport factors, and it will be interesting to test whether it is this domain that mediates interaction with nucleoporin repeat sequences.

\section{Materials and methods}

\section{Cell culture and transfection}

HtTA-1 cells (Gossen and Bujard, 1992) were cultured as described (Fornerod et al., 1995). In some experiments, actinomycin $\mathrm{D}_{1}$ (Boehringer Mannheim, Indianapolis, IN) or cycloheximide (Sigma, St Louis, MO) were added to the culture medium. Cell lines TTD2 and TTB6, which express HA1-CAN under the control of a tetracycline-dependent promoter, were created by co-transfecting HtTA-1 cells with SspI linearized plasmid pHA1-CAN (Fornerod et al., 1995) and ScaI linearized pJ $\Omega 6$ Puro at a molar ratio of 20:1. Puromycin-resistant clones were selected as described (Fornerod et al., 1995). TTD2 expressed HA1CAN predominantly in the nuclear envelope in the absence of tetracycline. Under these conditions, the cell line showed normal growth characteristics for multiple passages. The HA1-DEK-CAN-expressing cell line C4322 has been described previously, as has HtTA-1 transient transfection (Fornerod et al., 1995). Plasmid pHA1-Nup88(368-741) was created by placing sequences encoding two copies of the influenza virus HA1 tag (Fornerod et al., 1995) at the $5^{\prime}$ side of codons $368-741$ of the Nup 88 cDNA.

\section{Immunopurification}

Approximately $10^{10}$ TTD2 cells cultured on 500 15-cm dishes were rinsed once with phosphate-buffered saline (PBS), scraped in PBS and pelleted at $2000 \mathrm{~g}$ in $50 \mathrm{ml}$ tubes for $10 \mathrm{~min}$ at $4^{\circ} \mathrm{C}$. Cell pellets, in total weighing $40 \mathrm{~g}$ (wet weight) were frozen at $-80^{\circ} \mathrm{C}$ until further processing. TTD2 cell aliquots ( $2 \mathrm{~g}$ each) were transferred to $15 \mathrm{ml}$ tubes, lysed in $8 \mathrm{ml}$ ice-cold NP-40 lysis buffer (1\% NP-40, $50 \mathrm{mM}$ Tris- $\mathrm{HCl} \mathrm{pH} 8.0$, $150 \mathrm{mM} \mathrm{NaCl}, 5 \mathrm{mM}$ EGTA, $5 \mathrm{mM}$ EDTA, $15 \mathrm{mM} \mathrm{MgCl}_{2}, 60 \mathrm{mM}$ $\beta$-glycerolphosphate, $1 \mathrm{mM}$ DTT, $0.1 \mathrm{mM} \mathrm{NaVO}_{4}, 0.1 \mathrm{mM} \mathrm{NaF}, 15 \mathrm{mM}$ $p$-nitrophenylphosphate, $1.8 \mu \mathrm{g} / \mathrm{ml}$ aprotinin, $1 \mu \mathrm{g} / \mathrm{ml}$ leupeptin, $10 \mu \mathrm{g} / \mathrm{ml}$ 
soybean trypsin inhibitor, $0.1 \mathrm{mM}$ benzamidine), and filtered through $0.45 \mu \mathrm{m}$ cellulose acetate membranes. Lysates were then precleared for $30 \mathrm{~min}$ with $1 \mathrm{ml}$ packed Sepharose CL-4B (Pharmacia). HA1-CAN was immunoprecipitated by rotating the cleared lysates twice for $1 \mathrm{~h}$ with $0.4 \mathrm{mg}$ of monoclonal antibody $12 \mathrm{CA} 5$ (BAbCo, Newport, CA) covalently linked to $0.2 \mathrm{ml}$ packed CNBr-activated Sepharose CL-4B beads (Pharmacia). The beads were washed four times with $8 \mathrm{ml} \mathrm{NP}$ 40 lysis buffer and then once with PBS. Proteins were eluted from the Sepharose beads by subsequent batchwise elutions with $0.4,0.4$ and $0.2 \mathrm{ml} 0.5 \%$ SDS, and vacuum concentrated (Speed-Vac) to $250 \mu \mathrm{l}$. Proteins in the eluates were subsequently precipitated with 5 volumes acetone at room temperature and pelleted at $18000 \mathrm{~g}$ for $10 \mathrm{~min}$. The pellets were suspended in $25 \mu 1$ solubilization buffer (10\% SDS, $100 \mathrm{mM}$ $\mathrm{MgCl}_{2}, 50 \mathrm{mM}$ Tris-HCl pH 6.8, $0.1 \%$ bromophenol blue, $10 \%$ glycerol, $50 \mathrm{mM}$ dithiothreitol) by vortexing and heating to $90^{\circ} \mathrm{C}$. $50 \mu \mathrm{l}$ of this fraction, which represents proteins purified from $4 \mathrm{~g}$ of TTD2 cells, were loaded in $7 \mathrm{~mm}$ wide slots and separated on a $0.75 \mathrm{~mm} 6 \%$ polyacrylamide gel. Mock samples containing solubilization buffer alone were run in adjacent lanes to prevent the protein bands from fanning out. After electrophoresis, proteins were stained with Coomassie brilliant blue R250 (Bio-Rad, Hercules, CA), and excised from the gel. The protein in the gel slices was quantitated by laser desorbtion mass spectrometry (Williams et al., 1996). In-gel trypsin digestion, reversedphase HPLC and amino acid sequencing were subsequently performed as described (Williams and Stone, 1995).

\section{cDNA cloning}

cDNA clone IMAGE179414, encoding Nup88 peptides 50 and 67rep23, was obtained from Research Genetics (Huntsville, AL). cDNA clone HTTEU26, encoding hCRM1 peptide 63rep20 was obtained from Human Genome Sciences (Rockville, MD). Full-length cDNAs were obtained from a human placenta cDNA library (Hu2002B\#29203, Clonetech, Palo Alto, CA) and sequenced according to the established methodology (Sambrook et al., 1989).

\section{Antibodies}

Polyclonal antisera against hCRM1 and Nup88 were raised in rabbits by using recombinant protein produced in Escherichia coli BL21: DE3(pLysS) (Studier et al., 1990). hCRM1 amino acids 805-1071 and Nup88 amino acids 509-741 were expressed as glutathione $S$-transferase fusion proteins (Smith and Johnson, 1988) and were purified by using preparative SDS-PAGE and electroelution. The antisera were then affinity-purified by using these bacterial proteins immobilized on PVDF membrane as described previously (van Deursen et al., 1996).

\section{Immunoprecipitation and Western blotting}

HA1-tagged protein was immunoprecipitated from $\left[{ }^{3} \mathrm{H}\right]$ leucine-labeled cells as described (Fornerod et al., 1996). It is important to note that NP-40 lysis buffer extracts both cytoplasmic and nuclear proteins, as shown previously (Fornerod et al., 1996). hCRM1 and Nup88 were immunoprecipitated by the same procedure and by using purified antisera to the respective proteins at a dilution of 1 in 100 . Unlabeled HA1tagged protein was immunoprecipitated from $1 \times 10^{7}$ TTD2 or C4322 cells with $5 \mu \mathrm{g}$ of monoclonal antibody 12CA5 (Wilson et al., 1984). Following gel electrophoresis, proteins were either silver stained (Ansorge, 1985) or blotted onto PVDF membrane (Millipore, Bedford, MA). Blots were stained with india ink (Hancock and Tsang, 1983), blocked overnight in PBS containing $1 \%$ non-fat milk and $1 \%$ BSA, and then incubated for $3 \mathrm{~h}$ with affinity-purified $\alpha$-hCRM1 or $\alpha$-Nup88 antisera diluted to 1 in 100 in PBS/1\% non-fat milk. Bound antibody was visualized by adding a horseradish peroxidase-labeled secondary antibody (Jackson Laboratories, West Grove, PA), and using a commercial chemiluminescence kit (Dupont NEN, Boston, MA). The blots were washed in between antibody incubations five times for 5 min each in PBS/0.05\% Tween-20.

\section{Indirect immunofluorescence and immunoelectron} microscopy

HtTA-1 cells were fixed and permeabilized as described (Fornerod et al., $1995)$ and immunostained with affinity-purified $\alpha$-hCRM1 antibodies diluted to 1 in $90, \alpha$-Nup88 antibodies diluted to 1 in 30 , monoclonal 414 (BAbCo, Richmond, CA) at $5 \mu \mathrm{g} / \mathrm{ml}$, or monoclonal 12CA5 at $2 \mu \mathrm{g} / \mathrm{ml}$. Embryos from CAN $+1-$ heterozygous intercrosses were collected 3.5 days postcoitum and cultured in vitro for $\sim 18 \mathrm{~h}$ as described (van Deursen et al., 1996). CAN-/- embryos were identified at the onset of blastocoel contraction and fixed, alongside normal embryos (van Deursen et al., 1996). These embryos were then immunostained over- night with purified $\alpha$-hCRM1 or $\alpha$-Nup88 antibodies, both diluted to 1 in 30 , or monoclonal $414(5 \mu \mathrm{g} / \mathrm{ml})$, and images were collected by confocal laser scanning microscopy on a Bio-Rad MRC1000 (Bio-Rad, Hercules, CA) using a $\times 40$ oil objective.

HtTA-1 cells were examined by immunoelectron microscopy as previously described (Fornerod et al., 1995), except that cells were embedded in LR-White normal grade rather than in hard grade (London Rasin Company Ltd, Basingstoke, UK). Ultrathin cryosections were made and immunolabeled as described (Fransen et al., 1991). Sections were labeled with affinity-purified $\alpha$-hCRM1 antibodies diluted to 1 in 10 .

\section{Acknowledgements}

We thank Kathy Stone, Edward Papacoda and Dr Kenneth Williams of the W.M.Keck foundation for micro amino acid sequencing analyses, Sharon Frase and Dr Andrea J.Elberger for use of the confocal laser scanning facility, UT Memphis (funded by PHS Grant CLSM 1S10RR08385), Judith Boer for helpful discussions and critical reading of the manuscript, Huib Croes and Mietske Wijers for immunoelectron microscopy studies, Dr Sue Vallance for scientific editing, and Peggy Burdick for secretarial assistance. These studies were supported in part by Cancer Center CORE Grant CA-21765 and by the Associated Lebanese Syrian American Charities (ALSAC) of St Jude Children's Research Hospital.

\section{References}

Adachi,Y. and Yanagida,M. (1989) Higher order chromosome structure is affected by cold-sensitive mutations in a Schizosaccharomyces pombe gene $\mathrm{crml}^{+}$which encodes a $115-\mathrm{kD}$ protein preferentially localized in the nucleus and at its periphery. J. Cell Biol., 108, 1195-1207.

Adam,E.J.H. and Adam,S.A. (1994) Identification of cytosolic factors required for nuclear location sequence-mediated binding to the nuclear envelope. J. Cell Biol., 125, 547-555.

Adam,S.A. and Gerace,L. (1991) Cytosolic proteins that specifically bind nuclear localization signals are receptors for nuclear import. Cell, 66, 837-847.

Ansorge,W. (1985) Fast and sensitive detection of protein and DNA bands. J. Biochem. Biophys. Methods, 11, 13-20.

Belanger,K.D., Kenna,M.A., Wei,S. and Davis,L.I. (1994) Genetic and physical interactions between Srp1p and nuclear pore complex proteins Nup1p and Nup2p. J. Cell Biol., 126, 619-630.

Brinkmann,U., Brinkmann,E., Gallo,M. and Pastan,I. (1995) Cloning and characterization of a cellular apoptosis susceptibility gene, the human homologue to the yeast chromosome segregation gene CSE1. Proc. Natl Acad. Sci. USA, 92, 10427-10431.

Chi,N.C., Adam,E.J.H. and Adam,S.A. (1995) Sequence and characterization of cytoplasmic nuclear protein import factor $\mathrm{p} 97$. J. Cell Biol., 130, 265-274.

Chow,T.Y.-K., Ash,J.J., Dignard,D. and Thomas,D.Y. (1992) Screening and identification of a gene, PSE1, that affects protein secretion in Saccharomyces cerevisiae. J. Cell Sci., 101, 709-719.

Davis,L.I. and Blobel,G. (1986) Identification and characterization of a nuclear pore complex protein. Cell, 45, 699-709.

Fornerod,M. et al. (1995) Relocation of the carboxyterminal part of CAN from the nuclear envelope to the nucleus as a result of leukemiaspecific chromosome rearrangements. Oncogene, 10, 1739-1748.

Fornerod,M., Boer,J., van Baal,S., Morreau,H. and Grosveld,G. (1996) Interaction of cellular proteins with the leukemia specific fusion proteins DEK-CAN and SET-CAN and their normal counterpart, the nucleoporin CAN. Oncogene, 13, 1801-1808.

Forrester,W., Stutuz,F., Rosbash,M. and Wickens,M. (1992) Defects in mRNA 3 '-end formation, transcription initiation, and mRNA transport associated with the yeast mutation prp20: possible coupling of mRNA processing and chromatin structure. Genes Dev., 6, 1914-1926.

Fransen,J.A.M., Hauri,H.P., Ginsel,L.A. and Naim,H.Y. (1991) Naturally occurring mutations in intestinal sucrase-isomaltase provide evidence for the existence of an intracellular sorting signal in the isomaltase subunit. J. Cell Biol., 115, 45-57.

Goldstein,A.L., Snay,C.A., Heath,C.V. and Cole,C.M. (1996) Pleiotropic nuclear defects associated with a conditional allele of the novel nucleoporin Rat9p/Nup85p. Mol. Biol. Cell, 7, 917-934.

Görlich,D. and Mattaj,I. (1996) Nucleocytoplasmic transport. Science, 271, 1513-1518. 
Görlich,D., Prehn,S., Laskey,R.A. and Hartmann,E. (1994) Isolation of a protein that is essential for the first step of nuclear protein import. Cell, 79, 767-778.

Görlich,D., Kostka,S., Kraft,R., Dingwall,C., Laskey,R.A., Hartmann,E and Prehn,S. (1995a) Two different subunits of importin cooperate to recognize nuclear localization signals and bind them to the nuclear envelope. Curr. Biol., 5, 383-392.

Görlich,D., Vogel,F., Mills,A.D., Hartmann,E. and Laskey,R.A. (1995b) Distinct functions for the two importin subunits in nuclear protein import. Nature, 377, 246-248.

Görlich,D., Draft,R., Kostka,S., Vogel,F., Hartmann,E., Laskey,R.A., Mattaj,I.W. and Izaurralde,E. (1996) Importin provides a link between nuclear protein import and U snRNA export. Cell, 97, 21-32.

Gossen,M. and Bujard,H. (1992) Tight control of gene expression in mammalian cells by tetracycline-responsive promoters. Proc. Nat Acad. Sci. USA, 89, 5547-5551.

Grandi,P., Doye,V. and Hurt,E.C. (1993) Purification of NSP1 reveals complex formation with 'GLFG' nucleoporins and a novel nuclear pore protein NIC96. EMBO J., 12, 3061-3071.

Grandi,P., Emig,S., Weise,C., Hucho,F., Pohl,F., Pohl,T. and Hurt,E.C. (1995) A novel nuclear pore protein Nup82p which specifically binds to a fraction of Nsp1p. J. Cell Biol., 130, 1263-1273.

Guan,T., Muller,S., Klier,G., Panté,N., Blevitt,J.M., Haner,M., Paschal,B., Aebi,U. and Gerace,L. (1995) Structural analysis of the p62 complex, an assembly of O-linked glycoproteins that localizes near the central gated channel of the nuclear pore complex. Mol. Biol. Cell, 6, 1591-1603.

Hancock,K. and Tsang,V.C.W. (1983) India ink staining of proteins on nitrocellulose paper. Anal. Biochem., 133, 157-162.

Hurwitz,M.E. and Blobel,G. (1995) NUP82 is an essential yeast nucleoporin required for Poly(A)+ RNA export. J. Cell Biol., 130, 1275-1281.

Kadowaki,T., Goldfarb,D., Spitz,L.M., Tartakoff,A.M. and Ohno,M. (1993) Regulation of RNA processing and transport by a nuclear guanine nucleotide release protein and members of the Ras superfamily. EMBO J., 12, 2929-2937.

Kraemer,D., Wozniak,R.W., Blobel,G. and Radu,A. (1994) The human CAN protein, a putative oncogene product associated with myeloid leukemogenesis, is a nuclear pore complex protein that faces the cytoplasm. Proc. Natl Acad. Sci. USA, 91, 1519-1523.

Lupas,A., Van Dyke,M. and Stock,J. (1991) Predicting coiled coils from protein sequences. Science, 252, 1162-1164.

Melchior,F., Paschal,B., Evans,J. and Gerace,L. (1993) Inhibition of nuclear protein import by nonhydrolyzable analogues of GTP and identification of the small GTPase Ran/TC4 as an essential transport factor. J. Cell Biol., 123, 1649-1659. [published erratum appears in J. Cell Biol., 124, 217 (1994).]

Moore,M.S. and Blobel,G. (1993) The GTP-binding protein Ran/TC4 is required for protein import into the nucleus. Nature, 365, 661-663.

Moroianu,J., Hijikata,M., Blobel,G. and Radu,A. (1995) Mammalian karyopherin $\alpha_{1} \beta$ and $\alpha_{2} \beta$ heterodimers: $\alpha_{1}$ or $\alpha_{2}$ subunit binds nuclear localization signal and $\beta$ subunit interacts with peptide repeatcontaining nucleoporins. Proc. Natl Acad. Sci. USA, 92, 6532-6536.

Nehrbass,U. and Blobel,G. (1996) Role of the nuclear transport factor p10 in nuclear import. Science, 272, 120-122.

Nishi,K., Yoshida,M., Fujiwara,D., Nishikawa,M., Horinouchi,S. and Beppu,T. (1994) Leptomycin B targets a regulatory cascade of crm1, a fission yeast nuclear protein, involved in control of higher order chromosome structure and gene expression. J. Biol. Chem., 269, 6320-6324.

Panté,N. and Aebi,U. (1994) Toward the molecular details of the nuclear pore complex. J. Struct. Biol., 113, 179-189.

Panté,N. and Aebi,U. (1996) Toward the molecular dissection of protein import into nuclei. Curr. Opin. Cell Biol., 8, 397-406.

Panté,N., Bastos,R., McMorrow,I., Burke,B. and Aebi,U. (1994) Interactions and three-dimensional localization of a group of nuclear pore complex proteins. J. Cell Biol., 126, 603-617.

Perry,R.P. and Kelley,D.E. (1970) Inhibition of RNA synthesis by actinomycin D: characteristic dose-response of different RNA species. J. Cell Physiol., 76, 127-139.

Radu,A., Blobel,G. and Moore,M.S. (1995a) Identification of a protein complex that is required for nuclear protein import and mediates docking of import substrate to distinct nucleoporins. Proc. Natl Acad. Sci. USA, 92, 1769-1773.

Radu,A., Moore,M.S. and Blobel,G. (1995b) The peptide repeat domain of nucleoporin Nup98 functions as a docking site in transport across the nuclear pore complex. Cell, 81, 215-222.
Rexach,M. and Blobel,G. (1995) Protein import into nuclei: association and dissociation reactions involving transport substrate, transport factors, and nucleoporins. Cell, 83, 683-692.

Sambrook,J., Fritsch,E.F. and Maniatis,T. (1989) Molecular Cloning: A Laboratory Manual. Cold Spring Harbor Laboratory Press, Cold Spring Harbor, NY.

Schlenstedt,G. (1996) Protein import into the nucleus. FEBS Lett., 389, 75-79.

Schlenstedt,G., Wong,D.H., Koepp,D.M. and Silver,P.A. (1995) Mutants in a yeast Ran binding protein are defective in nuclear transport. EMBO J., 14, 5367-5378.

Simos,G. and Hurt,E.C. (1995) Nucleocytoplasmic transport: factors and mechanisms. FEBS Lett., 369, 107-112.

Siniossoglou,S., Wimmer,C., Rieger,M., Doye,V., Tekotte,H., Weise,C., Emig,S., Segref,A. and Hurt,E.C. (1996) A novel complex of nucleoporins, which includes Sec13p and a Sec13p homolog, is essential for normal nuclear pores. Cell, 84, 265-275.

Smith,D.B. and Johnson,K.S. (1988) Single-step purification of polypeptides expressed in Escherichia coli as fusions with glutathione S-transferase. Gene, 67, 31-40.

Sneath,P.H.A. and Sokal,R.R. (1973) Numerical Taxonomy. W.H.Freeman and Company, San Francisco, CA.

Studier,F.W., Rosenberg,A.H., Dunn,J.J. and Dubendorff,J.W. (1990) Use of T7 RNA polymerase to direct expression of cloned genes Methods Enzymol., 185, 60-89.

Sukegawa,J. and Blobel,G. (1993) A nuclear pore complex protein that contains zinc finger motifs, binds DNA, and faces the nucleoplasm. Cell, 72, 29-38

Toda,T., Shimanuki,M., Saka,Y., Yamano,H., Adachi,Y., Shirakawa,M., Kyogoku,Y. and Yanagida,M. (1992) Fission yeast pap1-dependent transcription is negatively regulated by an essential nuclear protein, crm1. Mol. Cell. Biol., 12, 5474-5484.

Turi,T.G., Webster,P. and Rose,J.K. (1994) Brefeldin a sensitivity and resistance in Schizosaccharomyces pombe. J. Biol. Chem., 269, 24229-24236.

van Deursen,J., Boer,J., Kasper,L. and Grosveld,G. (1996) $\mathrm{G}_{2}$ arrest and impaired nucleocytoplasmic transport in mouse embryos lacking the proto-oncogene CAN/Nup214. EMBO J., 15, 5574-5583.

von Lindern,M., Fornerod,M., van Baal,S., Jaeglé,M., de Wit,T., Buijs,A. and Grosveld,G. (1992a) The translocation (6;9), associated with a specific subtype of acute myeloid leukemia, results in the fusion of two genes, dek and can, and the expression of a chimeric, leukemiaspecific dek-can mRNA. Mol. Cell. Biol., 12, 1687-1697.

von Lindern,M., van Baal,S., Wiegant,J., Raap,A., Hagemeijer,A. and Grosveld,G. (1992b) can, a putative oncogene associated with myeloid leukemogenesis, can be activated by fusion of its $3^{\prime}$ half to different genes: characterization of the set gene. Mol. Cell. Biol., 12, 3346-3355.

Williams,K.R. and Stone,K.L. (1995) In gel digestion of SDS-PAGE separated proteins: Observations from internal sequencing of 25 proteins. In Crabb,J. (ed.), Techniques in Protein Chemistry. Academic Press, San Diego, CA, pp. 143-152.

Williams,K.R., Samandar,S.M., Stone,K.L., Saylor,M. and Rush,J. (1996) Matrix-assisted laser desorption ionization mass spectrometry as a complement to internal protein sequencing. In Walker,J.M. (ed.), The Protein Protocols Handbook. Humana Press, Totowa, NJ, pp. 541-555.

Wilson,I.A., Niman,H.L., Hougten,R.A., Cherenson,A.R., Connolly,M.L. and Lerner,R.A. (1984) The structure of an antigenic determinant in a protein. Cell, 37, 767-778.

Xiao,Z., McGrew,J.T., Schroeder,A.J. and Fitzgerald-Hayes,M. (1993) $C S E 1$ and CSE2, two new genes required for accurate mitotic chromosome segregation in Saccharomyces cerevisiae. Mol. Cell. Biol., 13, 4691-4702.

Received on August 20, 1996; revised on September 27, 1996 